\title{
Evaluation of Sexual Life Problems among Menopausal Woman with post-menopausal Bleeding at Maternity Hospitals in Baghdad City
}

\author{
Alaa Wahab Raheem ${ }^{1}$ Hawraa Hussein Ghafel ${ }^{1}$
}

'Maternal and Neonate Nursing Department, College of Nursing, University of Baghdad, Baghdad, Iraq.

*Correspondence to: Hawraa Hussein Ghafel (E-mail: hawraah@conursing.uobaghdad.edu.iq)

(Submitted: 08 April 2021 - Revised version received: 23 April 2021 - Accepted: 04 May 2021 - Published online: 26 June 2021)

\begin{abstract}
Objective To identify the sexual life problems among menopausal woman and to evaluate the levels of sexual life problems among menopausal woman.

Methods This study was conducted at maternity hospitals in Baghdad city to evaluate of sexual life problems among menopausal woman. This study was started in January 2021 to February 2021, The data regarding sexual life problems was achieved through the answering of women that attending maternity hospitals, the study consist of (200) women with menopausal age which were selected according to inclusion criteria (Women at menopausal age, Women with post-menopausal bleeding). The data are analyzed through the use of descriptive statistical analysis and inferential statistics.

Results Most of women are showing unproblematic sexual life and only (23.5\%) are showing problematic sexual life presents the mean of scores for evaluation the items of sexual life among women at menopause age; the mean scores indicate unproblematic among most of the items except the items that are related to (suffering from reduced sexual activity; they had regular sexual relations; suffering from a lack of sexual desire; and they cannot give their husband's marital rights) that are showing problematic.

Conclusion Most of menopausal women are showing unproblematic sexual life and they have normal and joyful sexual life regardless they suffering from post-menopausal bleeding.

Keywords sexual desire disorders, Menopause, Postmenopause, Women
\end{abstract}

\section{Introduction}

Human life is composed of different phases of lifeThe climatic era is one of these life phases that is unique to the female gender and that influences the life cycle of wome The reproductive stage ends in this period, ovarian functions cease, and anew stage begins for women in which they have lost their childbirth capacity This period starts at the age of about 40 and lasts until the age of $65 .{ }^{1}$ Sexuality can affect the quality of life by affecting a woman's emotional and psychological health. Clinicians who take care of women therefore understand whether they might be susceptible to sexual dysfunction. Sexual dysfunction is also associated with menopausal transition, aperiod marked by hormonal, physiological and social shifts. A decreasing and fluctuating gonadal steroid hormone is the physiological process through which themenopausal transition affects sexual health Menopause is associated with changes that affect sexuality in physiological and psychological terms. During menopause, a drop in the levels of circulating estrogen is the primary biological transition. Initially, estrogen deficiency accounts for modified bleeding and reduced vaginal lubrication ${ }^{3}$ Following menopause, a woman's body and sexual desire will shift due to the loss of estrogen and testosterone. Women who are menopausal or postmenopausal can note that they are less easily aroused and are less sensitive to touching and stroking. This can lead to a decrease in sex interest. Low estrogen levels may also result in a decrease in blood flow to the vaginal region. This can cause a drop in vaginal lubrication, leaving the vagina too dry for comfortable intercourse. ${ }^{4}$ In the lives of menopausal women, sexuality is an important aspect. Sexual dysfunction increases with age, despite the significance of sexual activity in menopausal females. ${ }^{5}$ While sex is central to female reproductive senescence, sexual activity and function decline with age. A substantial decrease from 74 to 56 percent in sexual activity.

$(P<0.001)$ between early postmenopausal women and late postmenopausl women has been recorded in the Women's Safe Ageing Project (WHAP) cohort, an extension of the Melbourne Women's Midlife Health Project, ${ }^{6}$ For many women, sexual interest persists, regardless of age and menopausal status. In the Analysis of Women's Health across the Nation (SWAN), 76\% of Middleaged women reported that sex was moderately or extremely significant to them.

\section{Methodology}

This study was conducted at maternity hospitals in Baghdad city to evaluate the Sexual Life Problems among Menopausal Woman. This study was started in January 2021 to February, 2021, the data regarding women's sexual life problems was achieved from the answering of women that attending maternity hospitals. Adescriptive study non-probability (a purposive sample) the study consist of (200) women with post-menopausal bleeding which were selected according to inclusion criteria that are (Women at menopausal age, Women with post-menopausal bleeding). This questionnaire was composed of three parts, part one: consists of sections that are related socio-demographic characteristics include (age, educational level, women occupation, Residency). Part two include: History of the menstrual period. Age at menarche (first menstrual period), Regularity of the menstrual cycle, Age when menopause and part three 
questions about sexual life of women with post-menopausal bleeding and the times of doing sexual intercourse per week. Reliability of questionnaire is determined through a pilot study and validity through panel (15) experts. Descriptive statistical analysis and inferential statistical analysis.

\section{Results}

Analysis of the sample related to socio-demographic and reproductive history characteristics of menopausal women; and describes the level sexual life problems among them.

This figure shows that most of women are showing unproblematic sexual life and only $23.5 \%$ are showing problematic sexual life.

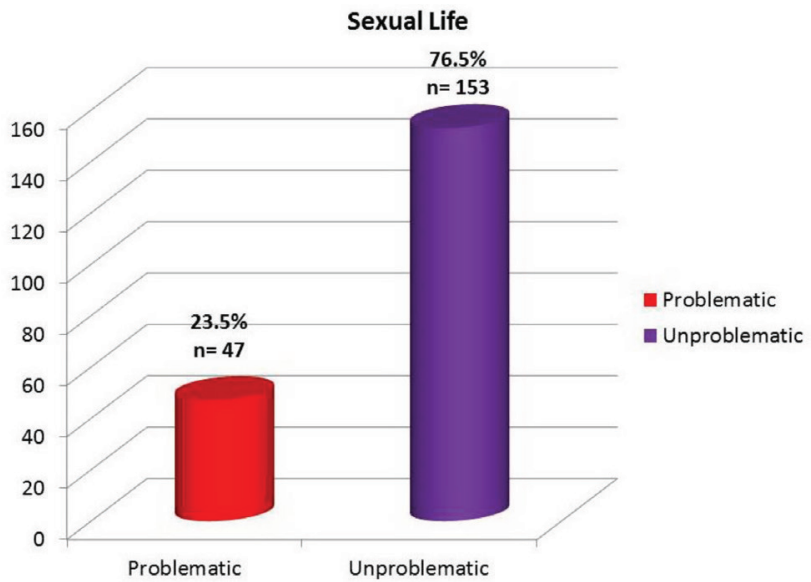

Fig. (1) Evaluation of Sexual Life Problems among Women at Age of Menopause $(\mathrm{N}=200)$

Table 1. Distribution of Women According to their Socio-demographic Characteristics

\begin{tabular}{|c|c|c|c|c|}
\hline List & Characteristics & & $\mathbf{F}$ & $\%$ \\
\hline \multirow{6}{*}{1} & \multirow{6}{*}{$\begin{array}{l}\text { Age } \\
(M \pm S D=53 \pm 4)\end{array}$} & $45-50$ year & 50 & 25 \\
\hline & & 51 - 55 year & 103 & 51.5 \\
\hline & & $56-60$ year & 37 & 18.5 \\
\hline & & $61-65$ year & 9 & 4.5 \\
\hline & & $66 \leq$ year & 1 & .5 \\
\hline & & Total & 200 & 100 \\
\hline \multirow{5}{*}{2} & \multirow{5}{*}{ Occupation } & Employee & 33 & 16.5 \\
\hline & & Housewife & 145 & 72 \\
\hline & & Retired & 20 & 10 \\
\hline & & Free profession & 2 & 1 \\
\hline & & Total & 200 & 100 \\
\hline
\end{tabular}

\begin{tabular}{|c|c|c|c|c|}
\hline \multirow{4}{*}{3} & \multirow{4}{*}{ Residency } & Urban & 83 & 41.5 \\
\hline & & Rural & 63 & 31.5 \\
\hline & & Sub-urban & 54 & 27 \\
\hline & & Total & 200 & 100 \\
\hline \multirow{7}{*}{4} & \multirow{7}{*}{$\begin{array}{l}\text { Level of } \\
\text { education }\end{array}$} & $\begin{array}{l}\text { Doesn't read \& } \\
\text { write }\end{array}$ & 71 & 35.5 \\
\hline & & Read \& write & 43 & 21.5 \\
\hline & & Primary school & 27 & 13.5 \\
\hline & & $\begin{array}{l}\text { Intermediate } \\
\text { school }\end{array}$ & 7 & 3.5 \\
\hline & & $\begin{array}{l}\text { Secondary } \\
\text { school }\end{array}$ & 18 & 9 \\
\hline & & $\begin{array}{l}\text { Institute/col- } \\
\text { lege }+\end{array}$ & 34 & 17 \\
\hline & & Total & 200 & 100 \\
\hline \multirow{7}{*}{5} & \multirow{7}{*}{$\begin{array}{l}\text { Current body } \\
\text { mass index }\end{array}$} & Underweight & 0 & 0 \\
\hline & & Normal weight & 0 & 0 \\
\hline & & Overweight & 7 & 3.5 \\
\hline & & Obese & 151 & 75.5 \\
\hline & & Severe obese & 37 & 18.5 \\
\hline & & Morbid obese & 5 & 2.5 \\
\hline & & Total & 200 & 100 \\
\hline \multirow{7}{*}{6} & \multirow{7}{*}{$\begin{array}{l}\text { Previous body } \\
\text { mass index }\end{array}$} & Underweight & 0 & 0 \\
\hline & & Normal & 0 & 0 \\
\hline & & Overweight & 114 & 57 \\
\hline & & Obese & 84 & 42 \\
\hline & & Sever obese & 2 & 1 \\
\hline & & Morbid obese & 0 & 0 \\
\hline & & Total & 200 & 100 \\
\hline
\end{tabular}

f: Frequency, \%: Percentage, M: Mean, SD: Standard deviation

This table shows that more than half of women are with age 51-44 year (51.5\%) with mean age $53 \pm 4$ year. The occupational status for them refers that $72 \%$ of them are housewives and $16.5 \%$ are still employee while $10 \%$ are retired. The residency variable shows that $41.5 \%$ of them are resident at urban area and $31.5 \%$ are resident in rural area. Regarding the level of education, the highest percentage among them refers to $35.5 \%$ that doesn't read and write and $21.5 \%$ of them are read and write. The current body mass index for women are refers that $75.5 \%$ of them are obese while the previous body mass index refers that they was overweight (57\%). The occupational status for them refers that $72 \%$ of them are housewives and $16.5 \%$ are still employee while $10 \%$ are retired.

Table 2. Evaluation of Sexual Life Problems among Menopause Women ( $\mathbf{N}=\mathbf{2 0 0})$

\begin{tabular}{llllll}
\hline List $\quad$ Items & Responses & $\mathbf{f}(\%)$ & M.S & Evaluation \\
\hline \multirow{2}{*}{$\begin{array}{l}* \\
\text { reduced sexual activity }\end{array}$} & Never & $12(6)$ & & \\
& & Sometimes & $85(42.5)$ & 2.46 & Problematic \\
\end{tabular}


Table 2. Evaluation of Sexual Life Problems among Menopause Women ( $\mathrm{N}=\mathbf{2 0 0}$ )

\begin{tabular}{|c|c|c|c|c|c|}
\hline List & Items & Responses & $f(\%)$ & M.S & Evaluation \\
\hline \multirow{3}{*}{2} & \multirow{3}{*}{ regular sexual relations } & Never & $7(3.5)$ & & \\
\hline & & Sometimes & $40(20)$ & 2.73 & Problematic \\
\hline & & Always & 153(76.5) & & \\
\hline \multirow{3}{*}{3} & \multirow{3}{*}{ lack of sexual desire } & Never & $5(2.5)$ & & \\
\hline & & Sometimes & $112(56)$ & 2.39 & Problematic \\
\hline & & Always & $83(41.5)$ & & \\
\hline \multirow{3}{*}{4} & \multirow{3}{*}{$\begin{array}{l}\text { I feel embarrassed by my husband for not meeting his } \\
\text { sexual demands }\end{array}$} & Never & $50(25)$ & & \\
\hline & & Sometimes & $107(53.5)$ & 1.97 & Unproblematic \\
\hline & & Always & $43(21.5)$ & & \\
\hline \multirow{3}{*}{5} & \multirow{3}{*}{ Bleeding negatively affected marital relationship } & Never & $56(28)$ & & \\
\hline & & Sometimes & $112(56)$ & 1.88 & Unproblematic \\
\hline & & Always & $32(16)$ & & \\
\hline \multirow{3}{*}{6} & \multirow{3}{*}{$\begin{array}{l}\text { relationship with husband is very weak due to } \\
\text { bleeding }\end{array}$} & Never & $55(27.5)$ & & \\
\hline & & Sometimes & $96(48)$ & 1.97 & Unproblematic \\
\hline & & Always & $49(24.5)$ & & \\
\hline \multirow{3}{*}{7} & \multirow{3}{*}{ Woman cannot give husband marital rights } & Never & $30(15)$ & & \\
\hline & & Sometimes & $86(43)$ & 2.27 & Problematic \\
\hline & & Always & $84(42)$ & & \\
\hline \multirow{3}{*}{8} & \multirow{3}{*}{$\begin{array}{l}\text { relationship with husband has become weak and } \\
\text { disjointed }\end{array}$} & Never & $112(56)$ & & \\
\hline & & Sometimes & $70(35)$ & 1.53 & Unproblematic \\
\hline & & Always & 18(9) & & \\
\hline \multirow{3}{*}{9} & \multirow{3}{*}{ Poor bonding and attention with husband } & Never & $75(37.5)$ & & \\
\hline & & Sometimes & $105(52.5)$ & 1.73 & Unproblematic \\
\hline & & Always & $20(10)$ & & \\
\hline \multirow{3}{*}{10} & \multirow{3}{*}{ talk with husband about sex } & Never & $11(5.5)$ & & \\
\hline & & Sometimes & $97(48.5)$ & 2.41 & Problematic \\
\hline & & Always & $92(46)$ & & \\
\hline \multirow{3}{*}{11} & \multirow{3}{*}{ pain when with sex } & Never & $15(7.5)$ & & \\
\hline & & Sometimes & $140(70)$ & 2.15 & Problematic \\
\hline & & Always & $45(22.5)$ & & \\
\hline \multirow{3}{*}{12} & \multirow{3}{*}{$\begin{array}{l}\text { You feel embarrassed to have sexual intercourse after } \\
\text { the menopause }\end{array}$} & Never & $39(19.5)$ & & \\
\hline & & Sometimes & $132(66)$ & 1.95 & Unproblematic \\
\hline & & Always & $29(14.5)$ & & \\
\hline \multirow{3}{*}{13} & \multirow{3}{*}{ husband does not care about woman like the past } & Never & $79(39.5)$ & & \\
\hline & & Sometimes & $101(50.5)$ & 1.71 & Unproblematic \\
\hline & & Always & 20(10) & & \\
\hline & & Never & $134(67)$ & & \\
\hline 14 & husband started wanting to marry another woman & Sometimes & $57(28.5)$ & 1.38 & Unproblematic \\
\hline & & Always & $9(4.5)$ & & \\
\hline & & Never & $93(46.5)$ & & \\
\hline 15 & $\begin{array}{l}\text { husband's behavior and temperament changed with } \\
\text { woman }\end{array}$ & Sometimes & $99(49.5)$ & 1.58 & Unproblematic \\
\hline & & Always & $8(4)$ & & \\
\hline & & & & & (Continued \\
\hline
\end{tabular}


Table 2. Evaluation of Sexual Life Problems among Menopause Women $(\mathrm{N}=\mathbf{2 0 0})$

\begin{tabular}{|c|c|c|c|c|c|}
\hline List & Items & Responses & $f(\%)$ & M.S & Evaluation \\
\hline \multirow{3}{*}{16} & \multirow{3}{*}{$\begin{array}{l}\text { husband's interest in sex decreased a lot as I got older } \\
\text { and bleeding }\end{array}$} & Never & $82(41)$ & & \\
\hline & & Sometimes & $107(53.5)$ & 1.65 & Unproblematic \\
\hline & & Always & $11(5.5)$ & & \\
\hline \multirow{3}{*}{17} & \multirow{3}{*}{ husband treated woman cruelly and violently } & Never & 195(97.5) & & \\
\hline & & Sometimes & $4(2)$ & 1.03 & Unproblematic \\
\hline & & Always & $1(0.5)$ & & \\
\hline \multirow{3}{*}{18} & \multirow{3}{*}{ husband is trying to get away from the house } & Never & $163(81.5)$ & & \\
\hline & & Sometimes & $31(15.5)$ & 1.22 & Unproblematic \\
\hline & & Always & $6(3)$ & & \\
\hline \multirow{3}{*}{19} & \multirow{3}{*}{$\begin{array}{l}\text { The effect of bleeding on husband, both physically } \\
\text { and psychologically }\end{array}$} & Never & $153(76.5)$ & & \\
\hline & & Sometimes & $40(20)$ & 1.27 & Unproblematic \\
\hline & & Always & $7(3.5)$ & & \\
\hline
\end{tabular}

f: Frequency, \%: Percentage, M.S: Mean of score

Unproblematic $=\geq 2$, Problematic $=2<$

This table presents the mean of scores for evaluation the items of sexual life among women at menopause age; the mean scores indicate unproblematic among most of the items except the items that are related to (reduced sexual activity; regular sexual relations; lack of sexual desire; and I cannot give my husband his marital rights) that are showing problematic

\section{Discussion}

Figure (1): Evaluation of sexual Life problems among women at age of menopause $(\mathrm{N}=200)$ shows that most of women are showing unproblematic sexual life and only $23.5 \%$ are showing problematic sexual life. The study support by (Hashemi et al., 2013) assess sexual attitudes and sexual function in Iranian women entering menopause. Women were on average (53-56) years old. Seventy percent of them had some kind of sexual problem. The feeling of dyspareunia differed significantly $(P=0.03)$ between three types of sexuality attitudes. Data on their attitudes, sexual desire, orgasm, and dyspareunia were compared and found to be substantially different. Significant differences ( $\mathrm{p}=0.03,0.04$, and 0.04 respectively). ${ }^{8}$

Sexuality different from person to another. Many factors can affect sexuality, including stress, illness, and age, and family, professional and social obligations. Whatever the cause, and sometimes lead to feelings of isolation, frustration, rejection or discontent.

Table 1, Shows that more than half of women are with age (51-44) year (51.5\%) with mean age $53 \pm 4$ year. supported by the study (Al-Turiahi ${ }^{1}$ et al., 2016) in his study This research included 140 postmenopausal women with paravaginal bleeding, whose ages ranged from 46 to 80 years old, with a mean age of 58.67 .2 years. ${ }^{9}$ The older women age and the presence of certain diseases and hormonal problems, the greater the risk of sexual life problems among menopausal woman, occupational status for them refers that $(72 \%)$ of them are housewives and (16.5\%) are still employee while (10\%)are retired.
The support by (Soheila Nazarpour, 2020) in his study A variety of personal and social factors can affect quality of life (QoL) after menopause. The aim of this study was to find out what factors are related to postmenopausal women's quality of life. ${ }^{10}$

The old women are not connected to the health reality and not participate in other activities in the community, such as health care training in the menopause stage. The residency variable shows that $(41.5 \%)$ of them are resident at urban area and $(31.5 \%)$ are resident in rural area. In contrast to studies conducted by Puri et al. in Chandigarh (7.7\%) and Dasgupta and Ray in West Bengal (rural women - 20\% and urban women $29.9 \%$ ), this study found a prevalence of $\mathrm{PMB}$ of 1.8 percent, which is poor. PMB affects two out of every 100 postmenopausal women in the research area in Tamil Nadu, India. ${ }^{11}$

Women of menopause and who live in the urban area and not knowing how to face the stages of natural change in the menopause s may also face problems in sexual life regarding the level of education, the highest percentage among them refers to $(35.5 \%)$ that doesn't read and write and $(21.5 \%)$ of them are read and write. The study disagree with (40.8\%) were primary school graduates(Yücel \& Eroğlu, 2013). ${ }^{12}$

The level of education and maturity in thinking has a great impact on knowing the quality of life and how to deal with sexual problemsthe menopause stageThe current body mass index for women are refers that $(75.5 \%)$ of them are obese while the previous body mass index refers that they was overweight (57\%). This results support by (Azhar Mousa 2016) who found BMI: Obesity was a clear factor Nearly all of the cases were married (96.4\%), and the majority of them were obese and overweight (97.3\%), with 43 (30.7\%) having a typical BMI. ${ }^{13}$

Menopausal women, suffer from slowing of the process of building up, metabolism and movement, with the absence of healthy food and regular exercise lead to increase in weight and reduces sexual desire

Table 2, Evaluation of Sexual Life Problems among Menopausal Women $(\mathrm{N}=200)$ This table presents the mean of scores for evaluation the items of sexual life among women at 
menopause age; the mean scores indicate unproblematic among most of the items except the items that are related to (reduced sexual activity; regular sexual relations; lack of sexual desire; woman cannot give husband his marital rights) that are showing problematic. This results support by (Johnson, 2019) a woman's body and sexual drive can change due to the loss of estrogen and testosterone. Women who are menopausal or postmenopausal can note that they are less easily aroused and less responsive to touching and stroking. As a result, sex can become less appealing. ${ }^{14}$

\section{Conclusion}

Most of menopausal women are showing unproblematic sexual life and they have normal and joyful sexual life regardless they suffering from post-menopausal bleeding

\section{References}

1. Yücel, Ç., \& Eroğlu, K. (2013). Sexual problems in postmenopausal women and coping methods. Sexuality and Disability, 31(3), 217-228.https:// www.researchgate.net/publication/257663261_Sexual_Problems_in_ Postmenopausal_Women_and_Coping_Methods

2. North American Menopause Society. (2012). The 2012 hormone therapy position statement of the North American Menopause Society. Menopause (New York, NY), 19(3), 257.

3. Bachmann, G. A., \& Leiblum, S. R. (2004). The impact of hormones on menopausal sexuality: a literature review. Menopause, 11(1), 120-130.

4. Reviewed by Traci C. Johnson, MD on May 16, (2019). Sex and Menopause

5. Thornton, K., Chervenak, J., \& Neal-Perry, G. (2015). Menopause and sexuality. Endocrinology and Metabolism Clinics, 44(3), 649-661.

6. Lonnèe-Hoffmann, R. A., Dennerstein, L., Lehert, P., \& Szoeke, C. (2014). Sexual function in the late postmenopause: A decade of follow-up in a population-based cohort of Australian women. The journal of sexual medicine, 11(8), 2029-2038.

7. Cain, V. S., Johannes, C. B., Avis, N. E., Mohr, B., Schocken, M., Skurnick, J., \& Ory, M. (2003). Sexual functioning and practices in a multi-ethnic study of midlife women: Baseline results from SWAN. Journal of sex research, 40(3), 266-276.

8. Hashemi, S., Tehrani, F. R., Simbar, M., Abedini, M., Bahreinian, H., \& Gholami, R. (2013). Evaluation of sexual attitude and sexual function in menopausal age; a population based cross-sectional study. Iranian journal of reproductive medicine, 11(8), 631

9. Hashemi, S., Tehrani, F. R., Simbar, M., Abedini, M., Bahreinian, H., \& Gholami, R. (2013). Evaluation of sexual attitude and sexual function in menopausal age; a population based cross-sectional study. Iranian journal of reproductive medicine, 11(8), 631

10. Nazarpour, S., Simbar, M., Ramezani Tehrani, F., \& Alavi Majd, H. (2020). Factors associated with quality of life of postmenopausal women living in Iran. BMC women's health, 20, 1-9.

11. Sindhuri, R., \& Dongre, A. R. (2018). Postmenopausal bleeding among rural women in Tamil Nadu, India: Mixed methods study. Indian journal of community medicine: official publication of Indian Association of Preventive \& Social Medicine, 43(4), 288.

12. Yücel, Ç., \& Eroğlu, K. (2013). Sexual problems in postmenopausal women and coping methods. Sexuality and Disability, 31(3), 217-228.

13. Al-Turiahi', A. M., El-Dine, F. A., \& Herez, S. H. (2016). Assessment of postmenopausal bleeding: a cohort case study.

14. Al-Turiahi', A. M., El-Dine, F. A., \& Herez, S. H. (2016). Assessment of postmenopausal bleeding: a cohort case study. 